\title{
HISTOCHEMICAL STUDIES OF FATTY ACID SYNTHESIZING ENZYMES IN FATTY LIVERS INDUCED BY ETHIONINE, CARBON TETRACHLORIDE AND ETHANOL
}

\author{
SHINSUKE KANAMURA \\ Department of Cytochemistry (Director Prof. Hideo Takamatsu) \\ Chest Disease Research Institute, Kyoto University, Kyoto
}

Received for publication May 30, 1968

\begin{abstract}
Fatty acid synthesizing enzyme activity was studied histochemically in the hepatic lobules of young male mice with fatty livers induced by ethionine, carbon tetrachloride or ethanol. In fatty livers induced by ethionine or carbon tetrachloride, even when the fatty changes were very slight, enzyme activity was decreased throughout the entire lobules and in the centrilobular areas there was sometimes very little or no activity. In livers with mild to moderate fatty changes very little enzyme activity was found only in the peripheral areas and in some cases no enzyme activity was observed throughout the lobules. Severe fatty changes caused complete loss of enzyme activity. In ethanol-induced fatty liver, no change in enzyme activity was observed even in livers with moderate to somewhat severe fatty changes. But severe fatty liver developed when the dose of ethanol was increased, and enzyme activity became negative. The change in intensity and distribution of enzyme activity in fatty livers induced by ethionine and by carbon tetrachloride was similar, whereas the change was different in fatty liver induced by ethionine or carbon tetrachloride from that in fatty liver induced by ethanol. In fatty livers induced by ethionine and carbon tetrachloride, an inverse relationship was observed between the distribution of fat droplets and fatty acid synthesizing enzyme activity.
\end{abstract}

It is well known that fatty liver can be induced by a number of agents and means in experimental animals. In recent years not a few biochemical and morphological works have been reported on the pathogenetic mechanisms of the development of fatty liver. Lombardi has restricted the number of basic and general pathogenetic mechanisms of fatty livers induced by a variety of agents to only three (13). According to him, the pathogenesis of fatty liver induced by ethionine or carbon tetrachloride probably differs from that of ethanol-induced fatty liver. The basic pathogenetic mechanism underlying the fatty liver induced in the rat by carbon tetrachloride and ethionine is a major block in the utilization of hepatic triglyceride, although the rate of synthesis of hepatic triglyceride remains normal, or nearly normal (10) and the synthesis of fatty acid in the liver is decreased $(1,7$,

The abbreviation used are: NADPH, nicotinamide adenine dinucleotide (reduced form); CoA, coenzyme A. 
10, 22). Ethanol-induced fatty liver is probably the result of several alterations of lipid metabolism. The fatty acids in the triglycerides that accumulate in the liver could be derived from peripheral fat depots (18) or from the liver, either by increased hepatic fatty acid synthesis $(12,19)$ or decreased hepatic fatty acid oxidation (19). Although the mechanisms of fatty livers induced by ethanol, ethionine and carbon tetrachloride are still not well understood, it could be said that fatty acid synthesis is decreased in fatty liver induced by ethionine or carbon tetrachloride and increased in ethanol-induced fatty liver. The present investigation was undertaken to define the alterations of intensity and distribution of fatty acid synthesizing enzymes in the hepatic lobules of mice with fatty livers induced by ethionine, carbon tetrachloride and ethanol.

\section{MATERIALS AND METHODS}

Tissues and Processing: Adult ddD mice reared on a standard pellet diet (MF, Oriental Kobo Co., Ltd. Tokyo) and weighing about $20 \mathrm{~g}$ were used in all experiments.

Ethionine : $15 \mathrm{hr}$ before the injection of ethionine all food was withdrawn and mice were given only water to drink during the experimental time. DL-ethionine was injected intraperitoneally as a $2.5 \%$ solution in halfstrength saline in a dosage of $0.07,0.13,0.25,0.5,0.75$ or $1 \mathrm{mg}$ per $\mathrm{g}$ of body weight (1 mg per $\mathrm{g}$ body weight in the case of rat, 17). Control animals received an equal volume of saline. Mice were sacrificed 3, 12 and $24 \mathrm{hr}$ later by cervical dislocation.

Carbon tetrachloride: Non-fasting mice were injected intraperitoneally with $1.5 \mathrm{ml}$ of carbon tetrachloride per $\mathrm{kg}$ body weight $(2.0 \mathrm{ml}$ per $\mathrm{kg}$ body weight in the case of rat, 1). Controls were injected with the same amount of distilled water. All the animals were fasted until they were killed by cervical dislocation 3, 12 and $24 \mathrm{hr}$ later.

Ethanol: Mice were fasted for $15 \mathrm{hr}$ before treatment and throughout the subsequent experimental period. Water was given ad libitum. Ethanol was given by stomach tube in doses of 3,4 or $6 \mathrm{~g}$ per $\mathrm{kg}$ body weight $(6 \mathrm{~g}$ per $\mathrm{kg}$ body weight in the case of rat, 14). Controls were given water. 3 and $12 \mathrm{hr}$ later, the animals were sacrifficed by cervical dislocation.

Blocks of tissue were removed rapidly from the livers and frozen on dry ice. Sections were cut $12 \mu$ thick in a cryostat and mounted on glass coverslips. The sections were then immersed in $0.2 \mathrm{ml}$ of reaction mixture in a weighing bottle (27) and incubated at $37^{\circ} \mathrm{C}$ for 3 to $4 \mathrm{hr}$. Next, the sections were treated with $0.1 \mathrm{M}$ acetate buffer at $\mathrm{pH} 5.4$ for $15 \mathrm{~min}$, washed in distilled water, immersed in $1 \% \mathrm{~Pb}\left(\mathrm{NO}_{3}\right)_{2}$ solution for $13 \mathrm{~min}$, washed in distilled water for $7 \mathrm{~min}$, treated with dilute yellow ammonium sulfide, washed in distilled water, fixed with $10 \%$ formalin and finally mounted on glycerin-jelly (27). Sections were also incubated in solutions containing only corresponding amounts of buffer and calcium chloride as controls. The cryostat sections on coverslips were also stained for fat with Sudan IV (11) after fixation with $10 \%$ formalin for $15 \mathrm{~min}$. 
Incubation medium employed (27): This contained in its final volume of $0.2 \mathrm{ml}$ : Capryl-CoA $0.6 \mu$ moles, malonyl-CoA $1.2 \mu$ moles, NADPH $5 \mu$ moles, glucose 6 -phosphate $5 \mu$ moles, mixture of equal amount of calcium laurate, myristate and palmitate ca. $0.5 \mathrm{mg}$, glycylglycine $10 \mu$ moles, $\mathrm{CaCl}_{2} 13 \mu$ moles. The $\mathrm{pH}$ was adjusted to 6.7 .

Reagents: Coenzyme-A. NADPH and glucose 6-phosphate were purchased from Sigma Chem. Co., St. Louis,Mo., (USA). Capryl-CoA was synthesized by the method of Seubert (16), and the yield was assayed by determining the free sulfhydryl content before and after hydrolysis with potassium hydroxide (28). Malonyl-CoA was synthesized by the method of Trams and Brady (29), and the yield was determined by the disappearance of the free sulfhydryl of CoASH (23).

\section{RESULTS}

Results are summarized in Fig. 5.

Very weak to marked fatty infiltration was found in the livers of all animals treated with ethionine, carbon tetrachloride or ethanol. It was more pronounced in mice treated with higher doses and increased with time. In fatty livers induced by carbon tetrachloride, the swelling of hepatic cells and hydropic change in the mid- and centrilobular areas was observed $3 \mathrm{hr}$ after administration. Karyorrhexis and karyolysis were also observed in the central areas. In fatty liver induced by ethionine and ethanol, such swelling of the hepatic cells was not found.

Fatty liver $3 \mathrm{hr}$ after the administration of ethionine: The early decrease in fatty acid synthesizing enzyme activity had already appeared throughout the entire lobules when very few small fat droplets were seen in the midand centrilobular areas with the smallest dose used $(0.07 \mathrm{mg} / \mathrm{g}$ body weight) (Fig. 2). After larger dose of ethionine $(0.13 \mathrm{mg} / \mathrm{g}$ body weight), moderate fatty infiltration appeared mainly in the centrilobular hepatic cells. Enzyme activity remained sometimes very weak in periportal areas, sometimes no activity was seen throughout lobules. With a still higher dose of the agent $(0.25 \mathrm{mg} / \mathrm{g}$ body weight or more), extreme fatty infiltration was seen throughout the lobules and no enzyme activity could be observed.

Fatty liver $3 \mathrm{hr}$ after the administration of carbon tetrachloride: Even in livers with very few fat droplets scattered throughout the lobules (with slightly more fat droplets in mid- and centrilobular areas), there was very little or no enzyme activity in the centrilobular portions, and the peripheral areas exhibited the weak activity. In fatty liver with weak fatty infiltration in the centrilobular portions, activity remained sometimes extremely weak only in the periphery, sometimes no activity was seen throughout the lobules (Fig. 3).

Fatty liver 12 and $24 \mathrm{hr}$ after the administration of ethionine or carbon tetrachloride: The tissue of all or almost the entire lobules showed severe fatty infiltration. No enzyme activity was observed in any liver section.

In fatty livers induced by both ethionine and carbon tetrachloride, 

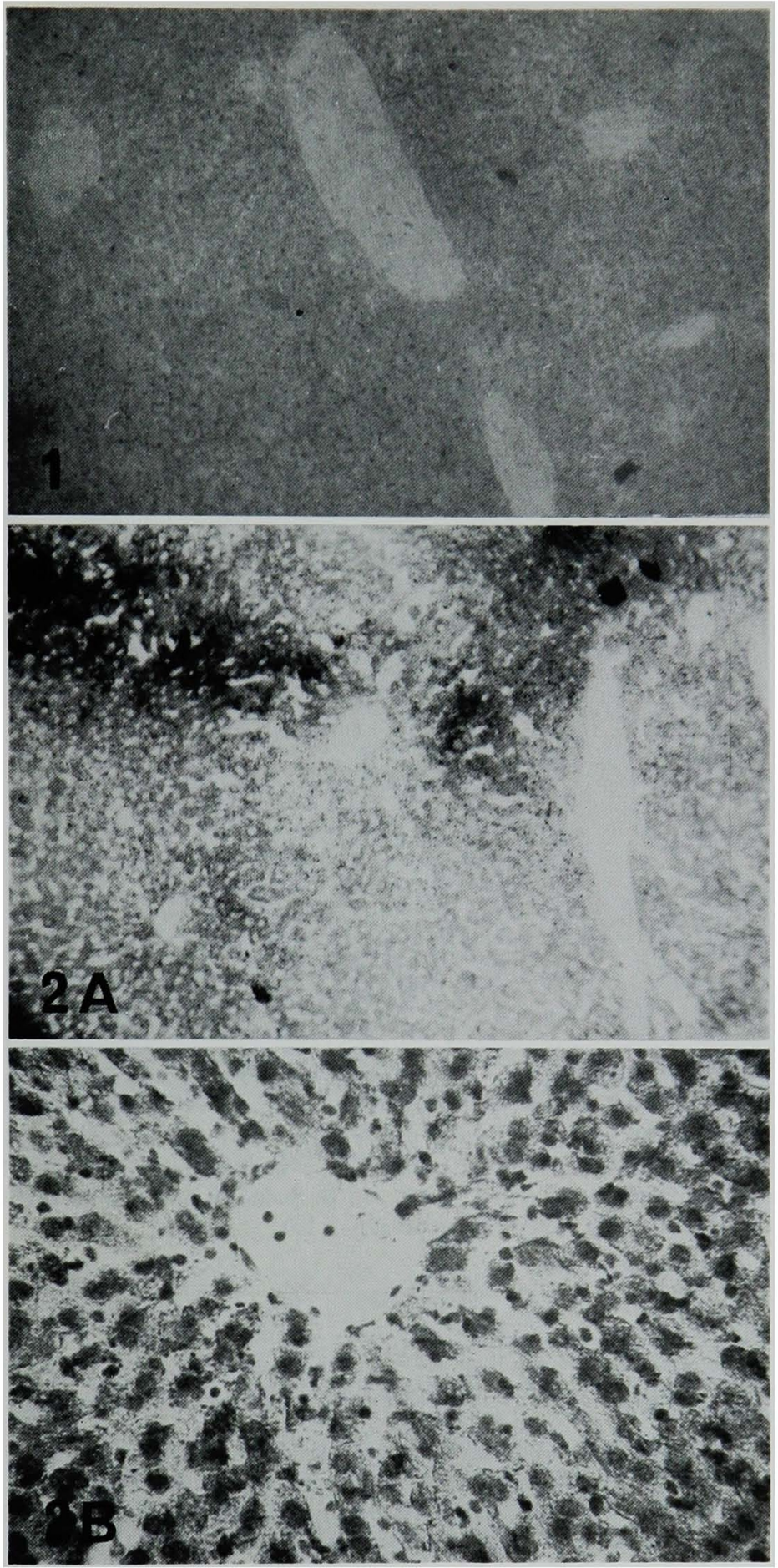


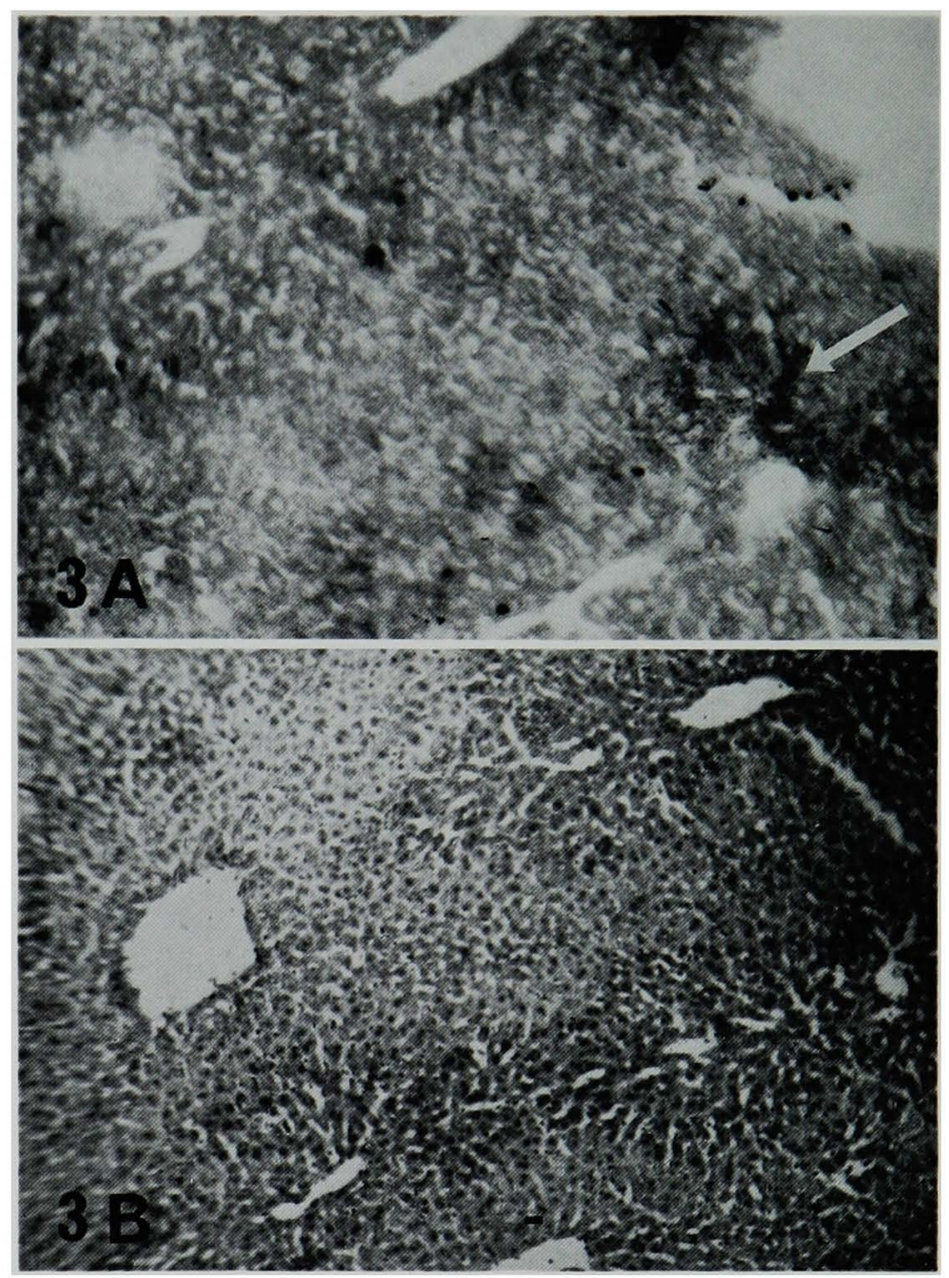

FIG. 3. Photomicrographs of liver of mouse 3 hours after administration of carbon tetrachloride $(1.5 \mathrm{~m} 1 / \mathrm{kg}$ body wt.) In $\mathrm{A}$, very weak activity in periportal areas or absence of activity is noted. $\times 150$ In B, Sudan IV stain shows slight fatty infiltration mainly in centrilobular areas. $\times 100$

FIG. 1. Photomicrograph of liver of control mouse. Fatty acid synthesizing enzyme activity is uniform throughout the lobule in a normal mouse liver. $\times 125$

FIG. 2. Photomicrographs of liver of mouse $3 \mathrm{hr}$ after administration of ethionine. $(0.07 \mathrm{mg} / \mathrm{g}$ body wt.) In $\mathrm{A}$, decrease in the enzyme activity is seen throughout the lobule. $\times 125$ In B, Sudan IV stain shows a very few fine fat droplets in the cells of mid-and centrilobular areas. $\times 400$ 


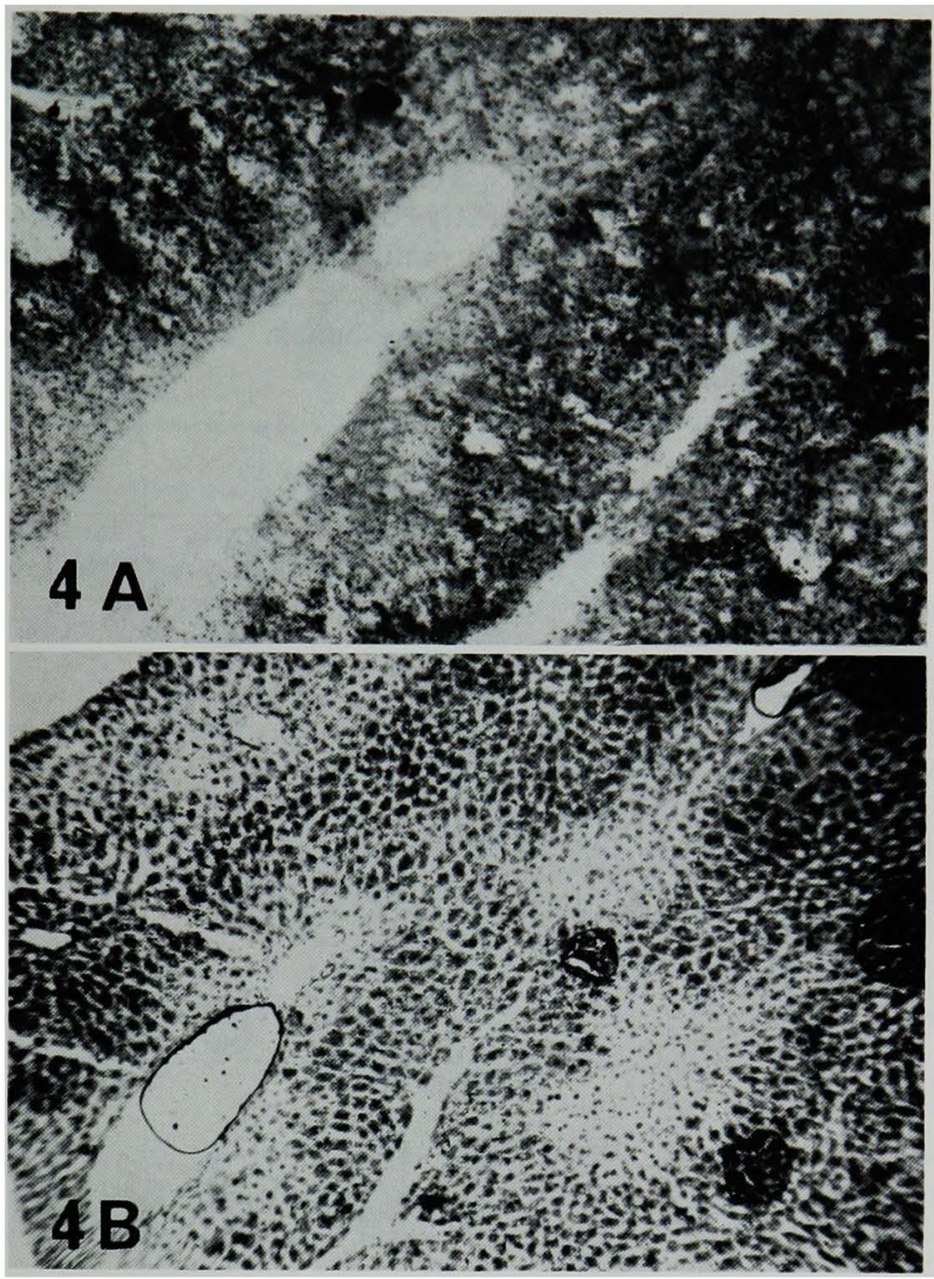

FIG. 4. Photomicrographs of liver of mouse $3 \mathrm{hr}$ after administration of ethanol $(3.0 \mathrm{~g} / \mathrm{kg}$ body wt.) In $\mathrm{A}$, there is no change in enzyme activity. $\times 150$ In $B$, Sudan IV stain shows moderate fatty infiltration mainly in centrilobular areas. $\times 100$

similar changes were noted in the intensity and distribution of enzyme activity during the development of fatty liver. With increasing fatty changes, the fat-loaded part of the hepatic lobule extended further towards the periphery. Inversely, fatty acid synthesizing enzyme activity disappeared from the central to the peripheral portion of the hepatic lobule (Fig. 6). In other words, an inverse relationship between the distribution of fat droplets and enzyme activity was found in the hepatic lobules of ethionine- and carbon tetrachloride-induced fatty livers.

Fatty liver $3 \mathrm{hr}$ after the administration of ethanol : Moderate fatty infiltra- 
tion was observed mainly in the central areas with a dose of $3 \mathrm{~g} / \mathrm{kg}$ body weight. Nevertheless, there was no decrease in fatty acid synthesizing enzyme activity in the livers with such moderate fatty changes as were noted with extremely reduced or no enzyme activity in ethionine- and carbon tetrachloride-induced fatty livers (Fig. 4). With higher dose of ethanol ( 4 or $6 \mathrm{~g} / \mathrm{kg}$ body weight) marked fatty changes were found throughout the entire lobules. The severely fatty infiltrating cells were negative for enzyme activity.

Fatty liver $12 \mathrm{hr}$ after the administration of ethanol: Somewhat severe fatty

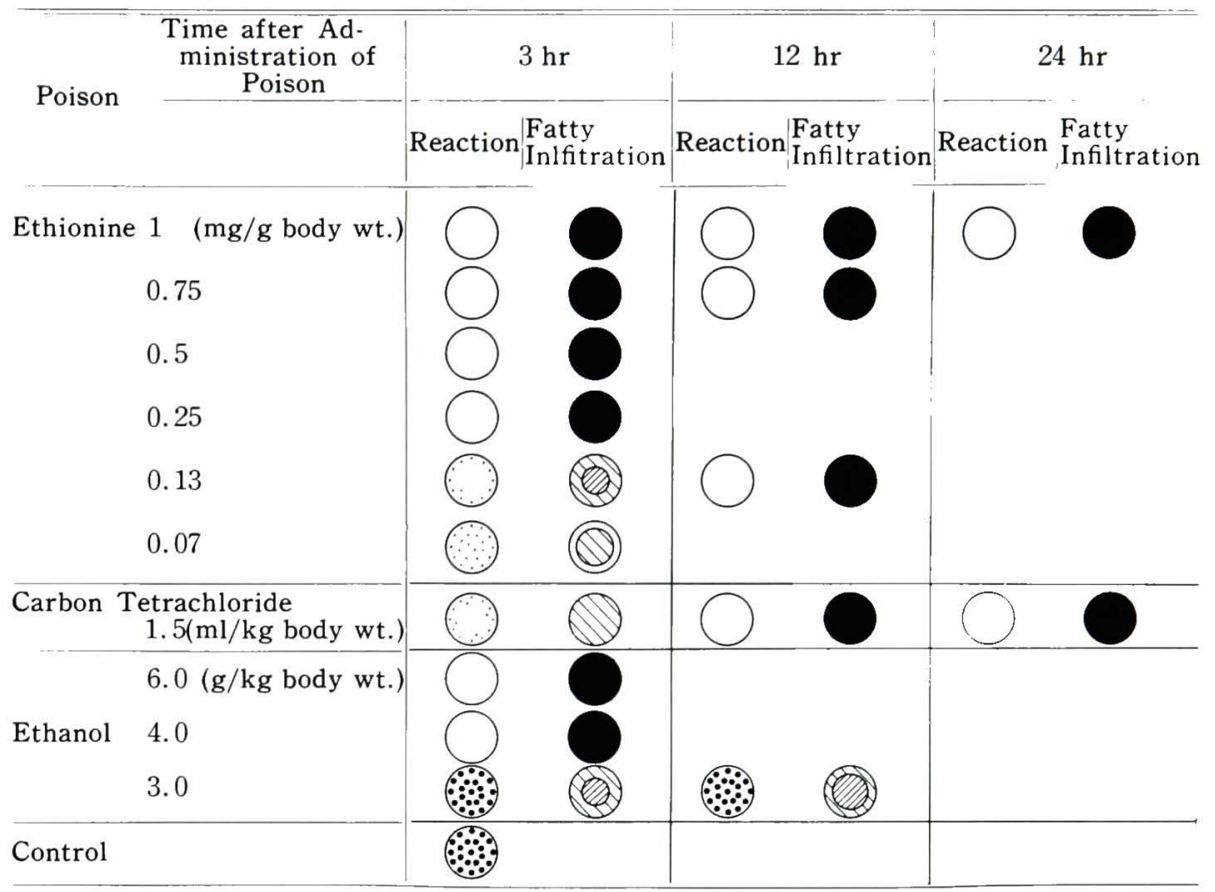

FIG. 5. Schematic representation of distribution of fatty acid synthesizing enzyme activity and fat droplets in hepatic lobule of acute fatty liver induced by ethionine, carbon tetrachloride or ethanol.

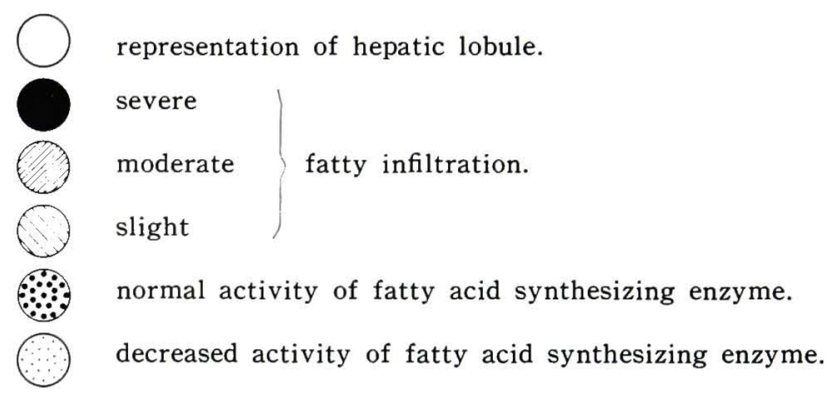




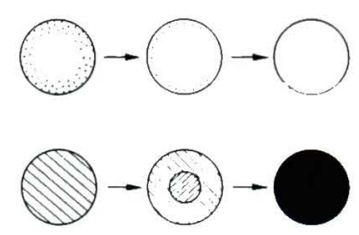

Change in distribution of fatty acid synthesizing enzyme activity in hepatic lobule during the development of fatty liver.

Change in distribution of fat droplets in hepatic lobule during the development of fatty liver.

FIG. 6. Schematic representation of inverse relation between distribution of fatty acid synthesizing enzymes and that of fatty infiltration in hepatic lobule of fatty liver induced by ethionine and carbon tetrachloride.

infiltration than that seen $3 \mathrm{hr}$ after the administration was observed mainly in the mid- and centrilobular areas, and, similary, no decrease in enzyme activity was noted.

The inverse relationship seen in ethionine- and carbon tetrachlorideinduced fatty livers was not found. The decrease in enzyme activity occurred for the first time in livers with somewhat severe fatty changes.

Control experiments: In the livers of animals receiving only saline or water after fasting for $15 \mathrm{hr}$, enzyme activity was uniform throughout the entire lobules of livers as in normal livers (Fig. 1). In the sections incubated in a medium containing only $\mathrm{CaCl}_{2}$ and glycylglycine, the reaction was blank, but positive reactions were seen at times. Particularly in the sections of ethanol-induced fatty liver a considerable amount of reaction products could be seen. The products were probably due to the enzymatic hydrolysis of the lipid accumulated in fatty livers (31).

\section{DISCUSSION}

Fatty liver can be induced in experimental animals by a number of agents. Rats are preferable in experiments on fatty liver, and there have been few reports on mouse fatty liver $(8,26,30,31,32)$. This paper describes the histochemical appearance of fatty liver in the mouse. Thus discussion assumes that the biochemical and morphological data on the mechanism of development of fatty liver in the rat can be applied without any alteration to that of fatty liver in the mouse.

The theoretical basis for the histochemical reaction used in this study for fatty acid synthesizing enzyme activity, which depends on the in vitro synthesis of long-chain saturated fatty acid from capryl-CoA, malonyl-CoA and NADPH, has been discussed recently elsewhere (27). As a result of the application of this technique to the study of mouse fatty livers induced by ethionine, carbon tetrachloride and ethanol, the following conclusion of reproducible reaction pattern of enzyme activity has been demonstrated. 1) in fatty liver induced by either ethionine or carbon tetrachloride, similarities were noted in the changed intensity and distribution of fatty acid synthesizing enzyme activity during the development of fatty liver, but there is an obvious difference in the change of enzyme activity in fatty 
liver induced by ethionine or carbon tetrachloride from that induced by ethanol. 2) In fatty liver induced by ethionine or carbon tetrachloride, the decrease in enzyme activity was already apparent in tissues with few or no fat droplets in the lobules, and loss of activity was noted in areas with slight to moderate fatty infiltration in the lobules. In ethanol-induced fatty liver there was no decrease in enzyme activity even in areas with somewhat marked fatty infiltration in the lobules, and loss of enzyme activity occurred for the first time in tissues with severe fatty infiltration in the lobules. 3) There is an inverse relationship between the pattern of distribution of fat droplets and that of enzyme activity in fatty liver induced by ethionine and carbon tetrachloride. This inverse relationship was not observed in ethanol-induced fatty liver.

It has been reported that the incorporation of acetate-1-C $\mathrm{C}^{14}$ into fatty acid in the microsomal-supernatant fraction of ethionine-treated rat liver diminishes with time. Three hr after administration, fatty acid synthesis in the liver was reduced to about $50 \%$ of that in the control (7). A similar phenomenon has been observed in fatty liver induced by carbon tetrachloride $(10,22)$. The incorporation of acetate into the fatty acid of the liver was reported to be little affected $3 \mathrm{hr}$ after the administration of carbon tetrachloride but greatly diminished after 24 hours (1). On the other hand, it has been reported that ethanol administration in rats stimulate the in vitro incorporation of acetate-1- $\mathrm{C}^{14}$ into liver lipid (19). Similarly, the incorporation of acetate-1- $\mathrm{C}^{14}$ is stimulated by the ethanol present in the incubation medium. Oxidation of ethanol in the rat liver results in reduction NAD and a shift in incorporation of acetate- $\mathrm{C}^{14}$ towards fatty acid synthesis (12). Thus, during the development of fatty liver induced by either ethionine or carbon tetrachloride there is a similar tendency in the change of fatty acid synthesis, and the rate of synthesis is diminished, while in ethanol-induced fatty liver different changes are observed, and fatty acid synthesis is increased. These biochemical data are not inconsistent with the present histochemical observations.

It was known that mitochondria in fatty liver are severely damaged (5). The endoplasmic reticulum, with which fatty acid synthesizing enzymes (chain elongation enzyme) are thought to be concerned $(15,25)$ is also damaged by carbon tetrachloride intoxication. It becomes fragmented and dilutes $(3,5,21)$. Bassi showed that the endoplasmic reticulum changes precede the mitochondrial changes in carbon tetrachloride intoxication (5). Furthermore, biochemical observations have shown that liver mitochondria are not the primary target of attack by carbon tetrachloride, but that glucose 6-phosphatase is the first enzyme to be affected (20). Cotutiu and Streja have reported that in carbon tetrachloride-induced fatty liver the first change observed is disappearance of glucose 6-phosphatase in the central area, and later, accumulation of fat droplets and loss of succinic dehydrogenase, and adenosine triphosphatase activity in the central zone are observed (6). Therefore, it is thought that in fatty liver in induced by carbon tetrachloride the endoplasmic reticulum is severely damaged and 
some microsomal enzymes are already affected earlier in the development of fatty liver and are the first enzyme system to be affected. In fatty liver induced by ethionine, striking change in ribosome organization with dispersal has been observed at earlier period of the administration (4). On the other hand, it has been shown that a single intoxicating dose of ethanol does not interfere with the integrity of the endoplasmic reticulum of the liver cell $(2,24)$. Lipoprotein synthesis and secretion by the liver are not impaired in the ethanol induced fatty liver (24). If these morphological changes in the endoplasmic reticulum are involved in the decrease in fatty acid synthesizing enzyme activity, the present results agree well with the morphological observations of fatty liver. That is, the decrease of enzyme activity is already present early in the development of fatty liver induced by ethionine or carbon tetrachloride as seen in glucose 6-phosphatase, while no decrease in enzyme activity can be seen till somewhat severe fatty infiltration appears in the hepatic cells in ethanol induced fatty liver.

The inverse distribution of fat and of oxidative enzymes (succinic dehydrogenase etc.) has also been reported in fatty liver induced by carbon tetrachloride (9). In these observations, the areas of tissue where strong activity existed and those with no activity were sharply delineated. In the present experiments, such a fine delineation as was seen in oxidative enzyme activity was not observed in fatty acid synthesizing enzyme activity in fatty liver induced by ethionine or carbon tetrachloride, but a definite inverse relationship was seen between the distribution of enzyme activity and of fat droplets.

Observations of oxidative enzyme activity in carbon tetrachloride intoxication (9) suggest that a decrease in fatty acid synthesizing enzyme activity seems to occur earlier than that of oxidative enzymes in fatty liver of similar degrees of severity. From this fact, fatty acid synthesizing enzymes seems to be more unstable than oxidative enzymes in fatty liver induced by carbon tetrachloride.

In the present study loss of enzyme activity was seen in tissue with slight to moderate degrees of fatty infiltration in the lobules of fatty liver induced by ethionine or carbon tetrachloride. In ethanol-induced fatty liver it was observed in tissue with somewhat severe fatty infiltration. In other words, liver cells, in which fat droplets have accumulated beyond a certain amounts, lose their ability to synthesize fatty acid regardless of the time after administration or dose of the agent. However, there is a definite difference in the degree of fatty infiltration at which a decrease or loss of enzym activity occurs between ethionine or carbon tetrachloride induced fatty liver and ethanol-induced fatty liver. From this fact, it could be assumed that the decrease in fatty acid synthesizing enzyme activity in fatty liver induced by ethionine or carbon tetrachloride depends on a different mechanism from that in ethanol-induced fatty liver and that the decrease in activity in ethanol intoxication probably results from the destruction of organelles by the marked fatty infiltration in hepatic cells. 


\section{ACKNOWLEDGMENT}

The author wishes to thank Professor Hideo Takamatsu for his continuing interest and encouragement and Professor Shiosaku Numa for his helpful advice on the preparation of capryl-CoA.

\section{REFERENCES}

1. Aiyar, A. S., Fatterpaker, P. and Sreenivasan, A.: Lipid metabolism in liver injury caused by carbon tetrachloride in the rat. Biochem. J. 90;558, 1964.

2. Ashworth, C. T., Wrightsman, F., Cooper, B. and Di Luzio, N. R.: Cellular aspects of ethanol-induced fatty liver: a correlated ultrastructural and chemical study. $J$. Lipid Res. 6; 258, 1965.

3. Ashworth, C. T., Luibel, F. J,, Sanders, E. and Arnold, N.: Hepatic cell degeneration. Arch. Path. 75; 212, 1963.

4. Baglio, C. and Farber. E.: Ultrastructural consequences of biochemical lesions in the liver incuced by ethionine. Fed. Proc. $24 ; 556,1965$.

5. Bassi, M.: Electron microscopy of rat liver after carbon tetrachloride poisoning. Exp. Cell. Res. 20; 313, 1960.

6. Cotutiu, C. and Streja, D.: Histochemical investigations of the liver in carbon tetrachloride poisoning. Acta Histochem. 23; 1, 1966.

7. Doering, C. H. and Natori, Y.: Studies on ethionine. VII. Fatty acid synthesis in livers of ethionine-treated rats. Proc. Soc. Exp. Biol. Med. 118; 957, 1964.

8. Eschenbrenner, A. B. and Miller, E. : Liver necrosis and induction of carbon tetrachloride hepatomas in strain A mice. J. Nut. Cancer Inst. 6; 325, 1946.

9. Friede, R. L. : Inverse histochemical distribution of fat and oxidative enzymes in fatty livers produced by carbon tetrachloride. J. Path. Bact. 79; 109, 1960.

10. Heimberg, M., Weinstein, I., Dishmon, G. and Dunkerley, A.: The action of carbon tetrachloride on the transport and metabolism of triglycerides and fatty acids by the isolated perfused rat liver and its relationship to the ethiology of fatty liver. J. Biol. Chem. 237; 3623, 1962.

11. Key, W. W. and Whitehead, R. J. : J. Path. Bact. 39; 449, 1934.

12. Lieber, C. S. and Schmid, R.: The effect of ethanol on fatty acid metabolism: Stimulation of hepatic fatty acid synthesis in vitro. J. Clin. Invest. 40; 394, 1961.

13. Lombardi, B.: Considerations on the pathogenesis of fatty liver. Lab. Invest. 15; 1, 1966.

14. Maling, H. M., Wakabayashi, M. and Horning, M. G.: Alterations in hepatic lipid biosynthetic pathways after ethanol, ethionine and carbon tetrachloride. In Advances in Enzyme Regulation, Vol. I., edited by Weber, G., Pergamon Press, New York, 1963, p. 247.

15. Nugteren, D. H.: The enzymic chain elongation of fatty acids by rat-liver microsomes. Biochim. Biophys. Acta 106; 280, 1965.

16. Numa, S., Ringelmann, E. and Lynen, F.: Zur Hemmung der Acetyl-CoA-Carboxylase durch Fettsäure-Coenzyme A-Verbindungen. Biochem. Z. 343; 243, 1965.

17. Olivecrona, T.: Plasma and liver lipids of ethionine-treated rats. Acta Physiol. Scand. 55; 291, 1962.

18. Poggi, M. and Di Luzio, N. R.: The role of liver and adipose tissue in the pathogenesis of the ethanol-induced fatty liver. J. Lipid Res. 5; 437, 1964.

19. Rebouqas, F. and Isselbacher, K. J.: Studies on the pathogenesis of the ethanolinduced fatty liver. I. Synthesis and oxidation of fatty acids by the liver. J. Clin. Invest. 40;1355, 1961. 
20. Recknagel. R. O. and Lombardi, B.: Studies of biochemical changes in subcellular particles of rat liver and their relationship to a new hypothesis regarding the pathogenesis of carbon tetrachloride fat accumulation. J. Biol. Chem. 236; 564, 1961.

21. Reynolds, E.S.: Liver parenchymal cell injury. I. Initial alterations of the cell following poisoning with carbon tetrachloride. J. Cell Biol. 19; 139, 1963.

22. Rubenstein, B. and Rubenstein, D.: The effect of carbon tetrachloride on hepatic lipid metabolism. Canadian J. Bioochem. 42; 1263, 1964.

23. Smith, S. and Dils, R.: Factors affecting the chain length of fatty acids synthesised by lactating-rabbit mammary glands. Biochim Biophys. Acta 116; 23, 1966.

24. Stein, O. and Stein, Y.: Fine structure of the ethanol induced fatty liver in the rat. Israel J. Med. Sci. 1; 378, 1965.

25. Stoffel, W. and Ach, K.: Der Stoff wechsel der ungesättigten Fettsäuren, II Eigenschaften des kettenverlängernden Enzyms. Zur Frage der Biohydrogenierung der ungesättigten Fettsäuren. Hoppe Seyler Z. Physiol. Chem. 337; 123, 1964.

26. Stowell, R. E. and Lee, C. S.: Histochemical studies of mouse liver after single feeding of carbon tetrachloride. Arch. Path. 50; 519, 1950.

27. Takamatsu, H., and Kanamura, S.: Histochemical demonstration of fatty acid synthesizing enzymes. Acta histochem. cytochem. 1; 114, 1968.

28. Toomey, R. E. and Wakil S. J.: Studies on the mechanism of fatty acid synthesis XVI. Preparation and general properties of acyl-malonyl acyl carrier protein-condensing enzyme from Escherichia coli. J, Biol. Chem. 241; 1159, 1966.

29. Trams, E. G., and Brady, R.O.: The synthesis of malony-C ${ }^{14}$ Coenzyme A. J. Amer. Chem. Soc. 82; 2972, 1960.

30. Tsuboi, K. K., Stowell, R. E. and Lee. C. S.: Chemical alterations induced in mause liver following a single feeding of carbon tetrachloride. Cancer Res. 11; 87, 1951.

31. Vokáč, V. and Hromádková, V.: Lokalisierung und Aktivität der Leberesterasen der Maus bei durch Hungern oder parenterale Verabreichung von Chlortetracyklin hervorgerufener Lebersteatose. Acta Histochem. 20; 260, 1965.

32. Starvation and fatty livers. Nutr. Rev, 21; 252, 1963. 